\title{
Biodiversity of Plants and Birds in Reclamation Area of PT Bukit Asam, Muara Enim, South Sumatera
}

\author{
Dimaz Danang Al-Reza ${ }^{1 *}$, Lilik Budi Prasetyo ${ }^{2}$, Rachmad Hermawan $^{2}$ \\ ${ }^{1}$ Graduated School of Bogor Agricultural University, Dramaga Main Road, Campus IPB Dramaga, Bogor, \\ Indonesia 16680. \\ ${ }^{2}$ Department of Forest Conservation and Ecotourism, Faculty of Forestry, Bogor Agricultural University, \\ Academic Ring Road, Campus IPB Dramaga, Bogor, Indonesia 16680
}

Received July 28, 2016/Accepted October 18, 2016

\begin{abstract}
Mining activities will reduce species diversity, whereas forest reclamation would restore the species diversity, which was previously a forested area. This research was conducted in PT Bukit Asam area, in 6 locations, and in natural forest, as a comparison. The objective of this research was identifying biodiversity of plants and birds in a reclamation area which had different planting years through an approach of diversity indices of vegetation and birds $\left(H^{\prime}\right)$, index of species similarity of plants and birds, and leaf area index (LAI). Research results showed that secondary succession occurred in the reclamation area. The value of plant diversity index in reclamation area of 1995 planting year exhibited diversity values which approached that of natural forest, except for undergrowth vegetation. Index of plant species similarity between reclamation area and natural forest did not show any presence of similar communities, but the reclamation area of 1995 planting year exhibited values of plant species similarity indices at all strata, ranging from undergrowth vegetation, seedlings, saplings, poles, and trees. Index of bird diversity in reclamation area of planting the year 1998 possessed the highest value and approached that of natural forest, namely 2.43. Reclamation area of 1998 planting year possessed the highest similarity index of bird species, namely 50\%. Reclamation area of the planting year 1995 possessed LAI which approached natural forest, namely 1.89. The older the planting year, the larger was the value of LAI, except for the disturbed reclamation area, namely reclamation area of 1996 planting year and reclamation area of 2001 planting year.
\end{abstract}

Keywords:diversity, LAI, natural forest, reclamation

*Correspondence author, email: dimazdanang@gmail.com,ph.: +62-89668030930

\section{Introduction}

Forests possess biodiversity of flora and fauna, and natural resources which are useful for all organisms. Disturbance toward the forests due to human activities will result in a reduction of biodiversity in the forests. One of such disturbances is mining activity, which will directly or indirectly change the environment. Mining activity also results in negative impacts such as: deforestation and forest degradation (Ardhana 2010; Puspaningsih et al. 2010, Mukhtar \& Heriyanto 2012), disturbed flora and fauna (Ardhana 2010; Riswan et al. 2015), sedimentation and erosion (Puspaningsih et al. 2010; Mukhtar \& Heriyanto 2012), and microclimate change (Mukhtar \& Heriyanto 2012). Due to such negative impacts, every mining company has obligation to return the area to forest condition, or in accordance with its allocated use, or obligation to do forest reclamation (Law of The Republic of Indonesia Number 4 of 2009).

Forest reclamation being conducted is revegetation activities to obtain sustainable utilization and development.
These activities have the objectives of repairing labile and unproductive lands and reduce erosion, and in the long term are expected to improve microclimate, restore biodiversity and improve land condition to be more productive (Riswan et al. 2015). Besides that, the existence of birds as seed dispersal agent will help in restoring the biodiversity potential which had ever existed in the mining area. Therefore, forest reclamation would indirectly restore the biodiversity potency in the mining area, which was previously in the form of natural forest. Birds could serve as a good indicator of biodiversity and environmental change (Bibby et al. 2000).

One of the mining companies which has conducted forest reclamation is PT Bukit Asam (PTBA) which is located in district of Muara Enim, the Province of South Sumatera. The objective of this research was identifying the biodiversity potency in the reclamation area.

\section{Methods}

This research was conducted in the area of PTBA, District 
of Muara Enim, the Province of South Sumatera in June 2015. This research was conducted in 6 reclamation areas with different planting year and secondary natural forest for comparison, and also in reclamation area with differing planting years, such as: the planting year 1995 (Udongan), planting the year 1996 (KL. Timur), the year 1998 planting (Mahayung 1), the year 2001 planting(Tupak), the year 2003 planting (SP 701), and the year 2004 planting (KTU). Distances between the natural forest and each reclamation area were respectively $2.59 \mathrm{~km}, 3.97 \mathrm{~km}, 3.86 \mathrm{~km}, 6.27 \mathrm{~km}$, $5.30 \mathrm{~km}$, and $3.97 \mathrm{~km}$. Map of research location in PTBA is shown in Figure 1.

Inventory of vegetation and birds Plots for vegetation analysis were constructed in reclamation area (Riswan et al. 2015 ) with size of $20 \mathrm{~m} \times 20 \mathrm{~m}$ for measuring trees, and within these plots there were plots of $10 \mathrm{~m} \times 10 \mathrm{~m}$ for measuring poles, plots of $5 \mathrm{~m} \times 5 \mathrm{~m}$ for measuring saplings, and plots of $2 \mathrm{~m} \times 2 \mathrm{~m}$ for measuring seedlings and undergrowth vegetation. In each research location, there were 5 plots of vegetation analysis with a distance of $100 \mathrm{~m}$ between plots. Plots were placed in a natural forest as control and in the reclamation areas in each different planting year. Data were collected for tree and pole stages, comprising species name, the number of species, and tree diameter. On the other hand, for saplings, seedlings, and undergrowth vegetation, the collected data comprise species name and number of individuals. The large of each reclamation area were planting the year 1995 has 34 ha, planting the year 1996 has 15.5 ha, planting the year 1998 has 15.5 ha, planting the year 2001 has 18.3 ha, planting the year 200319.4 ha and planting year 2004 has 21.7 ha.

Data collection for birds used binocular and combination between point count method or IPA (Indices Ponctuele $d$
'Abundance-Index of Abundance on Points) and transect method (Bibby et al. 2000). Observer stopped at a particular point and made a record of the encounter with the birds, comprising species of birds and number of birds, for 15 minutes. The observation was conducted in the morning, at $06.00-08.30$ hours Western Indonesia Time and in the afternoon at 14.30-17.00 hours. In each area, there was construction of working strip with the length of $1000 \mathrm{~m}$, with observation radius of $50 \mathrm{~m}$ and distance between points of $100 \mathrm{~m}$. The observation was conducted 3 times. Data collection was conducted 3 times. Data collection was conducted in natural forest and reclamation area in each different planting years.

Species composition and diversity index Vegetation composition in natural forest and in reclamation area of PTBA was studied by using a parameter of Importance Value Index (IVI). The mathematical formula being used in the calculation of vegetation analysis was based on Soerianegara \& Indrawan (2012). IVI is a result of the summation of Relative Density (RD), Relative Frequency (RF), and Relative Dominance for tree stage; or a summation result of $\mathrm{RD}$ and RF for undergrowth, seedling, and poles.

The diversity of species and birds could be calculated by using Shannon Index of Diversity $\left(\mathrm{H}^{\prime}\right)$. According to Magurran (2004), this index is calculated with the Equation [1]:

$\mathrm{H}^{\prime}=\sum_{i=1}^{\mathrm{s}}\left(\mathrm{p}_{\mathrm{i}} \operatorname{In} \mathrm{p}_{\mathrm{i}}\right)=\uparrow_{i=1}^{\mathrm{s}}\left[\left(\frac{n_{i}}{N}\right) \ln \left(\frac{n_{i}}{N}\right)\right]$

Note: $\mathrm{H}^{\prime}=$ Shannon diversity index; $\mathrm{N}=$ number of individuals of all species; $n_{i}=$ number of individuals of a species; $\mathrm{S}=$ number of species.

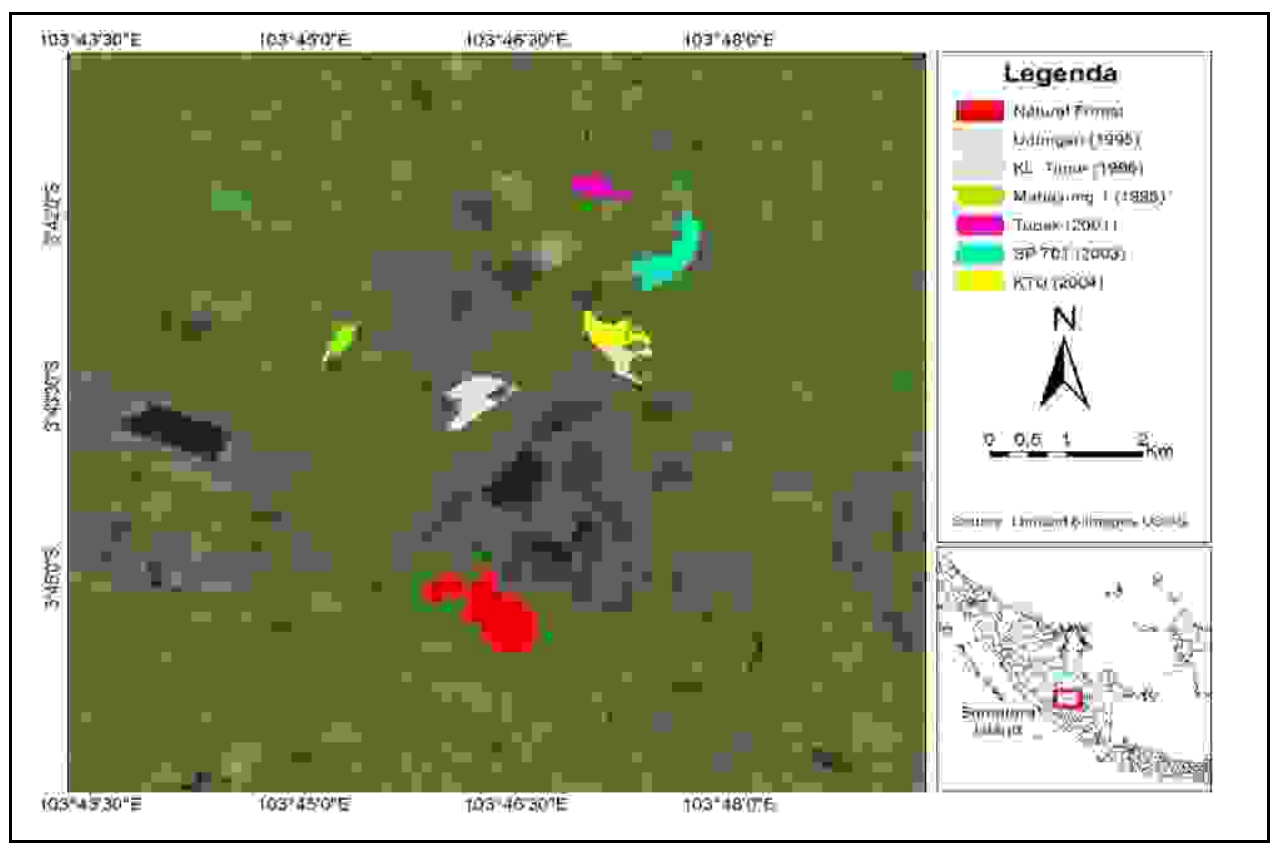

Figure 1 Map of research location in PTBA. 
Similarity index of plant species Index of similarity is needed to study the community. This index of similarity is based on Soerianegara and Indrawan (2012), and could be calculated with the following Equation [2]:

IS $=\frac{2 \mathrm{w}}{\mathrm{a}+\mathrm{b}} \subset 100 \%$

note: IS = index of similarity; $\mathrm{W}=$ summation of value which are similar and of the lowest, of the species which occur in the 2 communities being compared; $\mathrm{A}=$ summation of quantitative value of all species which occurred in the first stand, or community A; B $=$ summation of quantitative value all species which occurred in the second stand, or community B.

Index of similarity of bird species Habitat affects greatly the bird species composition in a community. Composition change in a habitat could be measured by Jaccard index of species similarity (Bengen 2000) for bird species, as shown as Equation [3].

IS $=\frac{a}{a+b+c} \subset 100 \%$

Note: $\mathrm{a}=$ number of species common in community A and $\mathrm{B} ; \mathrm{b}=$ number of species unique in community $\mathrm{A}$ but was absent in community $\mathrm{B} ; \mathrm{c}=$ number of species unique in community B, but was absent in community $\mathrm{A}$

Index of dominance of bird species Determination of dominant bird species in the research location was conducted by using the following formula of Helvoort (1981) as shown as Equation [4]:

$\mathrm{D}_{\mathrm{i}}=\frac{n_{i}}{N} \subset 100 \%$

Note: $\mathrm{Di}=$ index of dominance of a particular bird species; $\mathrm{n}_{\mathrm{i}}$ $=$ number of individuals of a particular bird species; $\mathrm{N}_{\mathrm{i}}=$ number of individuals of all bird species.

Criteria: $\mathrm{Di}=0-2 \%$, species is not dominant; $\mathrm{Di}=2-5 \%$, species is subdominant; $\mathrm{Di}=>5 \%$, species is dominant

Leaf area index (LAI) Recording of a crown cover picture with hemispherical photograph picture was conducted at 5 points within the $20 \mathrm{~m} \times 20 \mathrm{~m}$ observation plot. Data collection was conducted in natural forest and reclamation area in each different planting years. DSLR camera type canon 1100D, equipped with SIGMA circular fisheye lens to take a crown cover picture, was used with camera upper position, when the camera was directed to the sky, faced toward the north (Rich 1990), using the tripod with the elevation of $\pm 1 \mathrm{~m}$. Photograph of the crown cover was analyzed using software hemiview 2.1. For obtaining the LAI value, threshold method was applied to the photograph of crown cover with standard procedure to maximize contrast between foliage and the sky (Gardingen et al. 1999).

\section{Results and Discussion}

Species composition and plant species diversity index importance value index IVI of a species would indicate the dominance level of a particular species toward other species in a community. Species which has the highest IVI could have the greater chance to maintain growth and its species sustainability (Mawazin \& Subiakto 2013). High IVI could also indicate a high hierarchy or dominance (Saharjo \& Gago 2011). Species which has higher IVI would be more stable, from the point of view of species survival and growth. A large value of IVI also indicates the magnitude of effect which the species exert on a plant community (Indriyanto 2006). The species that have been planted were Acacia auriculiformis, A. mangium, Pterocarpus indicus, Cassia siamea, Leucaena glauca, Paraserianthes falcataria, Schima wallichii, and Melaleuca cajuputi. The species and amount of species that planted in each reclamation area were different.

Table 1 shows that secondary natural forest possessed the greatest number of plant species as compared to reclamation area. On the other hand, at undergrowth vegetation stage the number of plant species were same within reclamation area, and this was due to the phenomena that the natural forest, which was situated near PTBA, was a forest territory which was near to plantation of local people community, occurrence of illegal logging, and occurrence of land clearing for expansion of PTBA's mining area. The amount of undergrowth vegetation in natural forest influenced by vegetation trees about that directly correlate with the high value of LAI in natural forest. Ariani et al. (2014) explained that 1 of the factor causing less found undergrowth vegetation in the natural forest, is a high density of vegetation trees.

In reclamation area, the greatest number of undergrowth

Table 1 Number of species found in natural forest and each reclamation area

\begin{tabular}{lccccc}
\hline Location & $\begin{array}{c}\text { Undergrowth } \\
\text { vegetation }\end{array}$ & Seed ling & Saplings & Poles & Trees \\
\hline Natural forest & 11 & 11 & 12 & 7 & 7 \\
Udongan (1995) & 6 & 8 & 9 & 6 & 4 \\
KL. Timur (1996) & 11 & 6 & 4 & 6 & 6 \\
Mahayung 1 (1998) & 8 & 6 & 6 & 3 & 4 \\
Tupak (2001) & 8 & 2 & 7 & 3 & 3 \\
SP. 701 (2003) & 9 & 5 & 8 & 3 & 3 \\
KTU (2004) & 9 & 2 & & & 2 \\
\hline
\end{tabular}


vegetation species was found in the planting year 1996, namely 11 species; whereas that of the lowest occurred in the planting year 1995, namely 6 species. A number of species at seedling stage was highest in the planting year 1995, namely 8 species; whereas that of the lowest, namely 2 species, was found in the planting year 2001, namely A. auriculiformis and L. glauca, whereas those in the planting year 2004 were Microcos tomentosa and Bridelia tomentosa. At sapling stage, the greatest number of plant species was found in the planting year 1995, namely 9 species, whereas the smallest number of species was found in the planting year 1996, namely 4 species. At pole stage, the greatest number of plant species, namely 6 species, was found in the planting year 1995 and the planting year 1998. At tree stage, the greatest number of species, namely 4 species, was found also in the planting year 1995, and the planting year 1998, whereas that of the lowest, namely 2 species, was found in the planting year 2004. A number of plant species at seedling, sapling, pole, and tree stage in the planting year 1995 reclamation areas was greatest as compared with other reclamation areas because the planting year 1995 was the oldest reclamation area.

Figure 2 shows that at the undergrowth vegetation, the dominant and common species found in all reclamation area was Scleria sumatrana. In a natural forest, $S$. sumatrana was also the most dominant undergrowth species with IVI of $65.47 \%$. Among the undergrowth vegetation species growing in the reclamation area, there were several species which were also found in the natural forest. This phenomenon showed the occurence of secondary succession in each reclamation area. Such dominant species were among others: S. sumatrana, Saccharum spontaneum, and Eupatorium odoratum. These undergrowth vegetation species played a very great role in reclamation activities, particularly in restoring soil fertility in the ex-mining area. In the ex-mining area, undergrowth vegetation created many benefits for the environment, such as helping the soil aggregates to become not too easy to be detached and eroded by rainfall or runoff water (Hilwan et al. 2013).

Figure 3 shows that at the seedling stage, the dominant species and those which grow naturally in the reclamation area were among others: Leea indica, B. tomentosa, and $M$. tomentosa. In reclamation area, those seedling species possessed IVI $>30 \%$. This phenomenon shows that $L$. indica, B. tomentosa, and $M$. tomentosa played very great role because their IVI were more than $10 \%$. A species at seedling stage is categorized as having significant role if its IVI is more than $10 \%$ (Mawazin \& Subiakto 2013). Plant species $L$. indica, B. tomentosa, and $M$. tomentosa were natural species without being planted, and this shows the occurrence of secondary succession in the reclamation area. Reclamation area which possessed natural and dominant plants were among others: planting year 1995, planting year 1996, planting year 1998, and planting year 2004. This phenomenon shows that nature was able to perform natural succession in reclamation area. Vegetation pattern in the reclamation area being studied showed the occurrence of natural succession and was useful to optimize the development of reclamation strategy (Das et al. 2015).

Other seedling species which were nonlocal species, such as L. glauca, A. auriculiformis, $P$. indicus, and A. mangium were species intentionally planted by PTBA as pioneer species. The existence of local species in the mining area, which can become dominant at the seedling stage, was supposed probably due to the role of nonlocal or pioneer species which had previously grown in the area so that there was some shade to the local species. Besides that, it was supposed also that seed dispersal was conducted by the bird. The role of bird is as plant destroyer, while also act as a dispersal agent for several plant species' seeds (Husain et al. 2010).

Figure 4 shows that secondary succession occurred up to

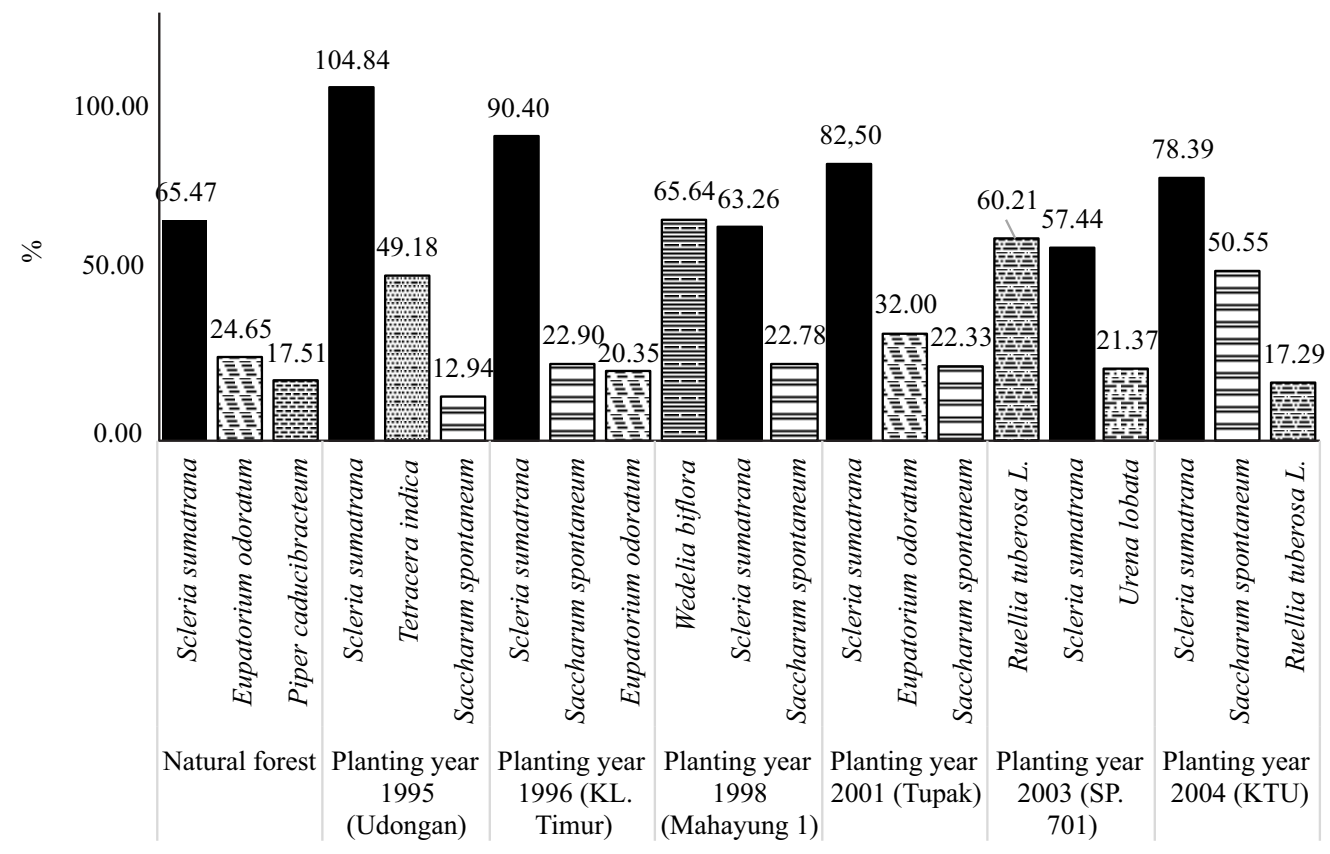

Figure 2 Three species with the highest IVI for undergrowth vegetation in natural forest and reclamation area. 


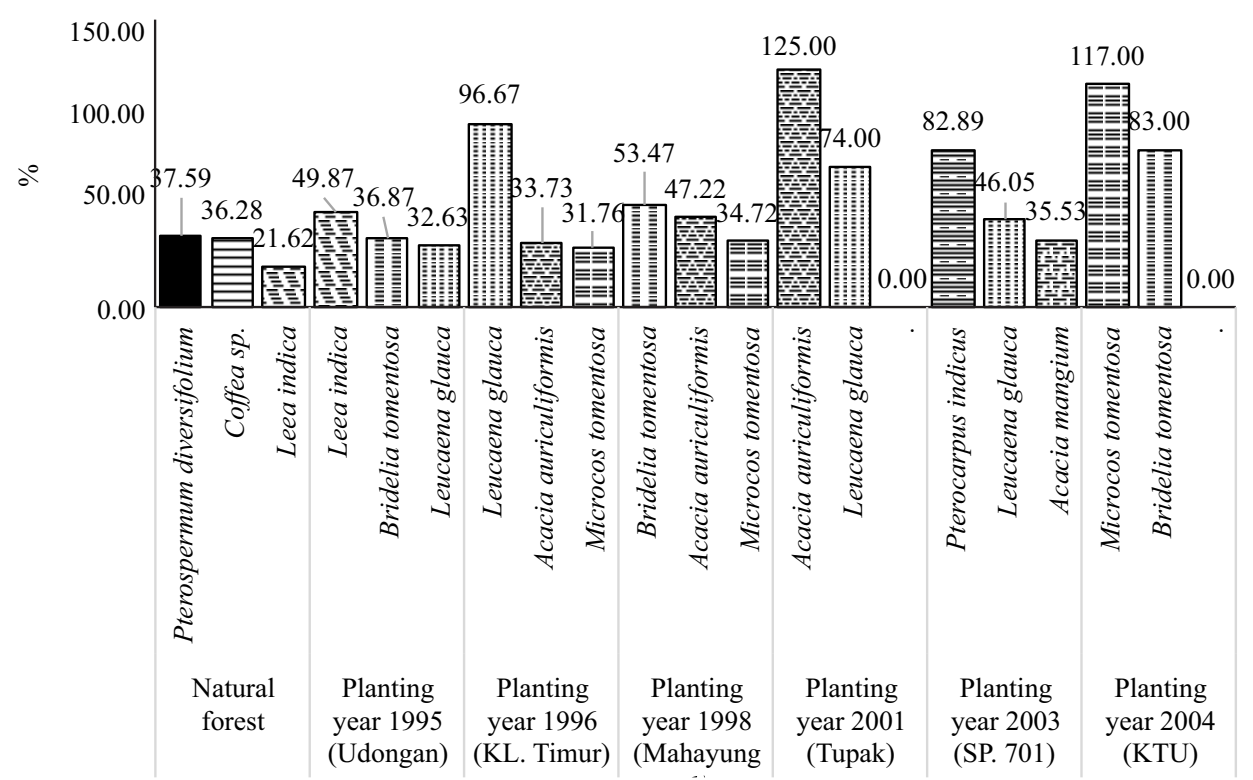

Figure 3 Three species with the highest IVI for the seedling stage in natural forest and reclamation area.

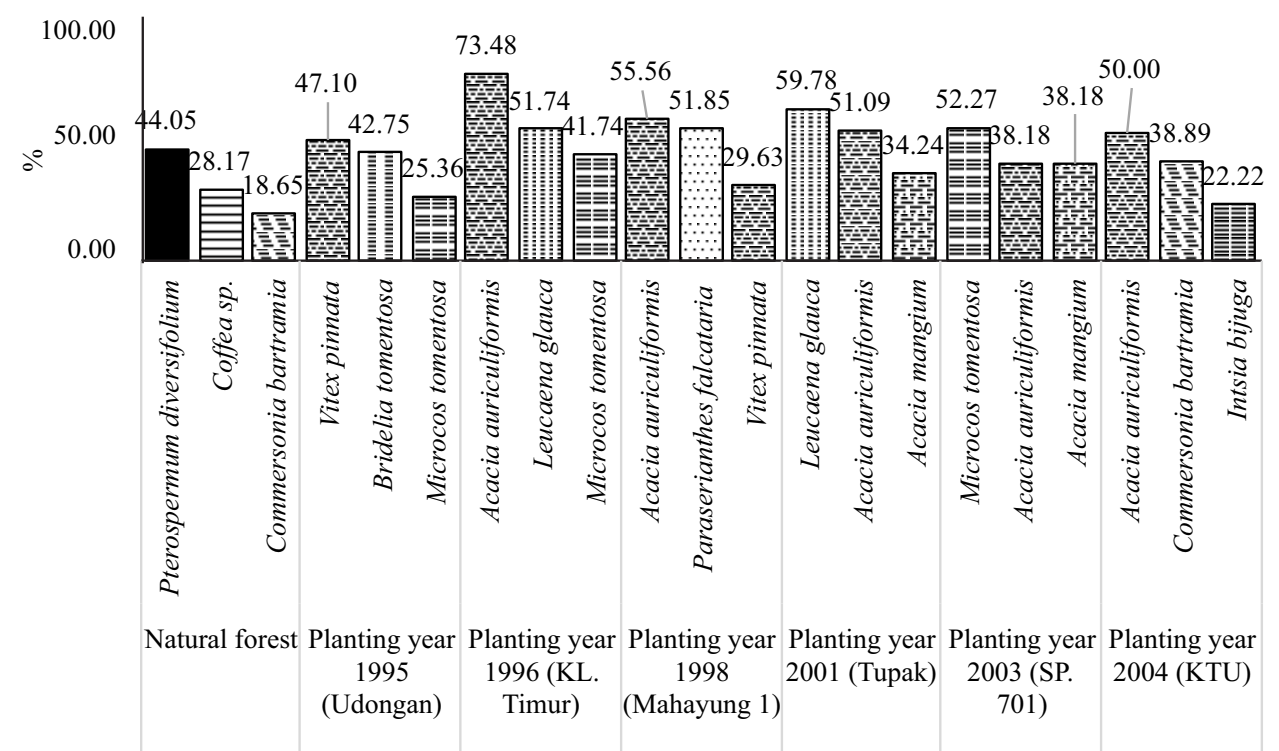

Figure 4 Three species with highest IVI at sapling stage in natural forest and reclamation area.

sapling stage. Such plant species were among others: Vitex pinnata, B. tomentosa, M. tomentosa, and Commersonia bartramia. The planting year 1995 possessed 3 dominant plant species which constituted species which grew naturally in the natural forest, whereas other reclamation areas which possessed dominant natural forest was reclamation areas planting year 1996, 1998, 2003, and 2004. A large number of dominant local species was the influence of the attribute of oldest reclamation planting year as compared with other reclamation areas.

Figure 5 shows that plant species of pole stage which could grow naturally and dominant were only found in reclamation area with planting year 1995, 1996, and 1998. Those plant species were among others: $V$. pinnata, $B$. tomentosa, and $M$. tomentosa. This was due to $B$. tomentosa and M. tomentosa can be producing fruit as a food source for the animal (Wirdateti et al. 2005; Hadisiswoyo et al. 2014). Birds contribute to the spread of fruit/seeds plants, so the species can spread and dominant in each reclamation area. Riswan et al. (2015) explained that some indigenous flora species that found and grown in the coal mined lands in PT. Bukit Asam South Sumatera, among other: $V$. pinnata, Oplismenus burmannii, and Melastoma sylvaticum. This phenomenon shows that secondary succession up to pole stage occurred in a reclamation area which possessed old planting year, namely above 15 years.

Figure 6 shows that natural plant species which could grow and dominant, up to tree stage were $V$. pinnata and Pterygota alata. Secondary succession at tree stage occurred only in reclamation area of planting year 1995, although they 


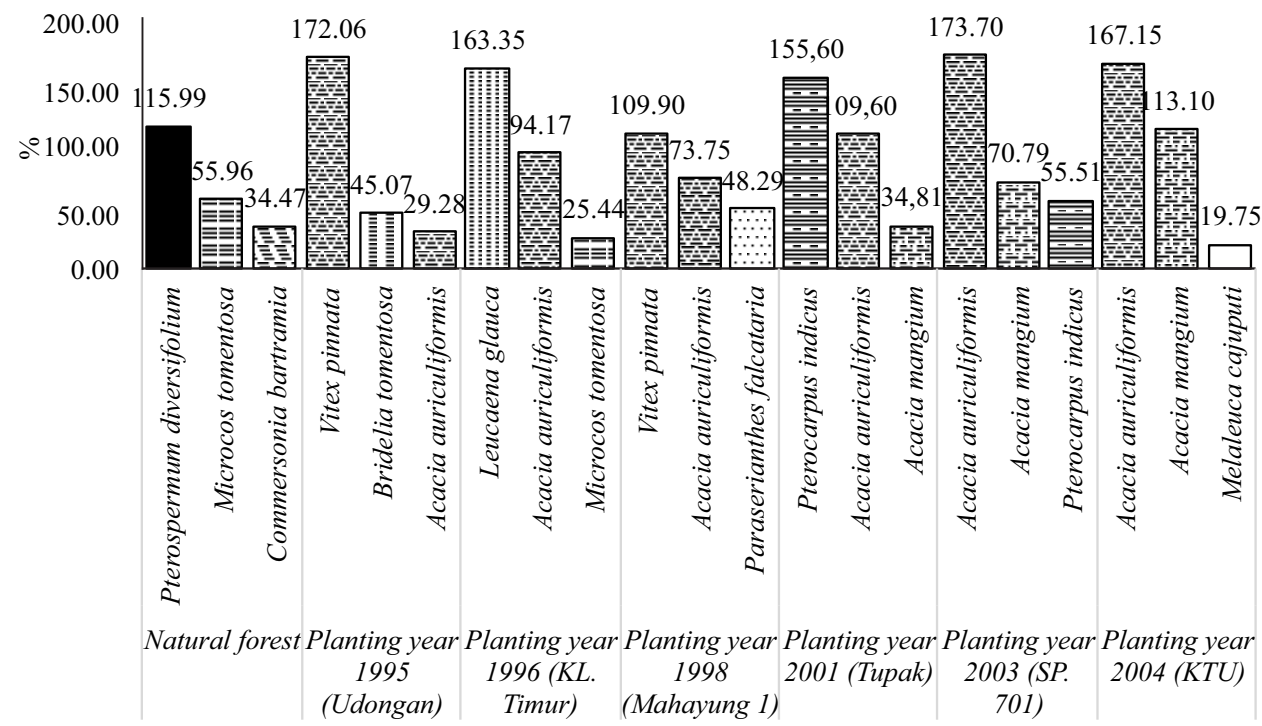

Figure 5 Three species with the highest IVI at pole stage in natural forest and reclamation area.

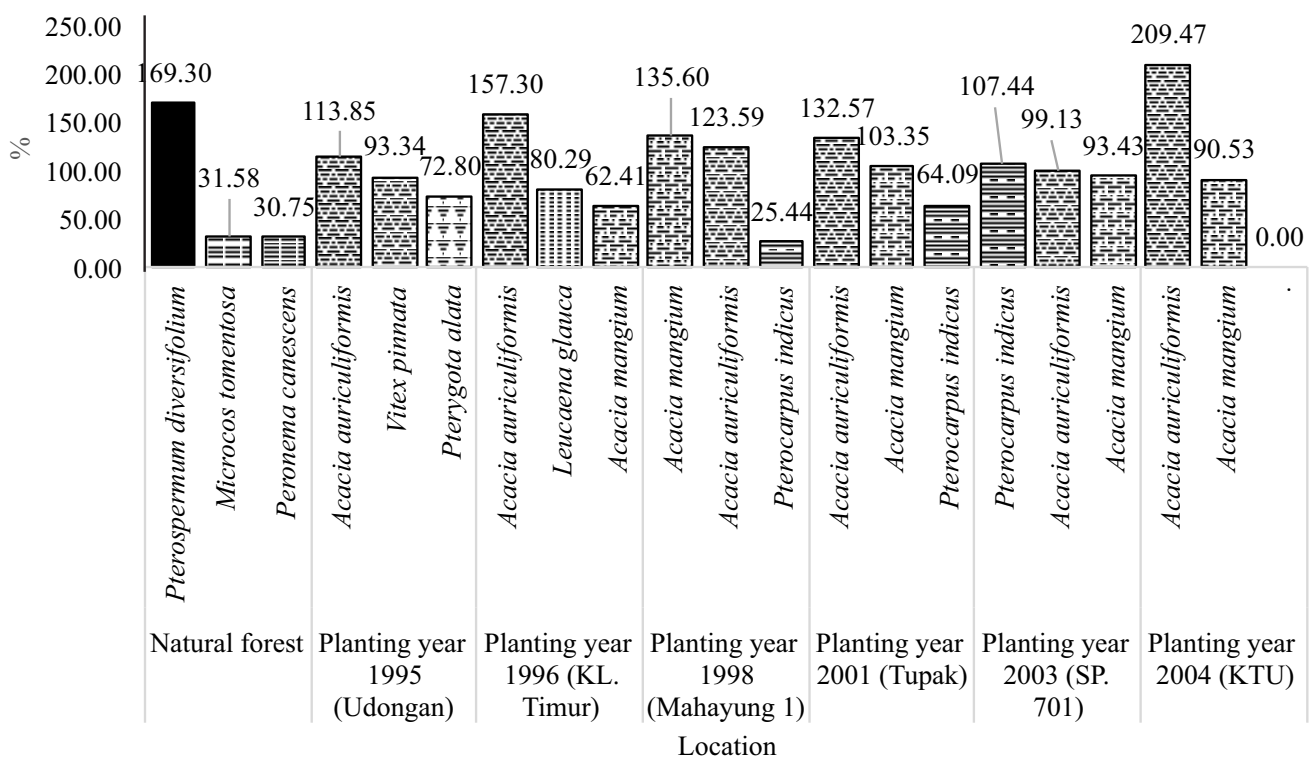

Figure 6 Three species with highest IVI at tree stage in natural forest and reclamation area.

were dominant only at $2^{\text {nd }}$ and $3^{\text {rd }}$ position, whereas other reclamation areas were dominated by pioneer plant species which were intentionally planted by PTBA for reclamation area, comprising species such as A. auriculiformis, L. glauca, $A$. mangium, and $P$. indicus. This phenomenon shows that secondary succession occurred up to tree stage, in a reclamation area which possessed old planting year, namely more than 20 years.

Table 2 shows that species diversity level at each growth stage varied significantly. The value of $\mathrm{H}^{\prime}$ in natural forest ranged between $1.33-2.24$ which implied that diversity in the natural forest was categorized as moderate. Diversity values $\left(\mathrm{H}^{\prime}\right)$ of $1.0<\mathrm{H}^{\prime}<3.322$ showed that the diversity is moderate, productivity is sufficient, the ecosystem is in a balanced condition and ecological pressure is in balance (Fitriana 2006). Growth stages of seedling, sapling, pole, and tree possessed values of $H^{\prime}$ in planting the year 1995 and 1998 , which ranged between $1.0<\mathrm{H}^{\prime}<3.322$, and this implies that the diversity was categorized as moderate. Values of $\mathrm{H}^{\prime}$ for seedling, sapling, pole and tree stages in the planting year 1995 possessed diversity values which approached that of natural forest. This was due to the fact that this reclamation area had the attribute of old planting year. Diversity tends to increase in an older community, whereas in the newly formed community, the diversity is low (Odum 1993). Among the values of $\mathrm{H}^{\prime}$ in the planting year 1996, 2001, 2003, and 2004 their values of $\mathrm{H}^{\prime}<1.0$, and this indicates the value of $\mathrm{H}^{\prime}$ was low. Fitriana (2006) explained that value of $<1.0$ implies that the diversity is low, and the productivity was very low, as an indication that there were heavy pressure and the ecosystem was not stable.

The value of 'H' of undergrowth vegetation was 1.78, indicating a moderate category. On the other hand, $\mathrm{H}^{\prime}$ value for undergrowth vegetation was highest in reclamation area, 
Table 2 Plant diversity indices $\left(\mathrm{H}^{\prime}\right)$

\begin{tabular}{lccccc}
\hline \multicolumn{1}{c}{ Location } & $\begin{array}{c}\text { Undergrowth } \\
\text { vegetation }\end{array}$ & Seedling & Sapling & Pole & Tree \\
\hline Natural forest & 1.78 & 2.19 & 2.24 & 1.63 & 1.33 \\
Udongan (1995) & 0.80 & 1.83 & 1.90 & 1.23 & 1.20 \\
KL. Timur (1996) & 1.28 & 1.08 & 1.29 & 0.90 & 0.92 \\
Mahayung 1 (1998) & 1.15 & 1.63 & 1.60 & 1.44 & 1.06 \\
Tupak (2001) & 1.28 & 0.69 & 1.53 & 0.90 & 1.08 \\
SP. 701 (2003) & 1.19 & 1.19 & 1.76 & 0.93 & 1.08 \\
KTU (2004) & 1.18 & 0.64 & 1.84 & 0.81 & 0.57 \\
\hline
\end{tabular}

Table 3 Index of plant species similarity

\begin{tabular}{|c|c|c|c|c|c|c|c|}
\hline \multirow[b]{2}{*}{ Control } & \multirow[b]{2}{*}{ Vegetation structure } & \multicolumn{6}{|c|}{ Reclamation area $(\%)$} \\
\hline & & $\begin{array}{c}\text { Udongan } \\
(1995)\end{array}$ & $\begin{array}{c}\text { KL. Timur } \\
(1996)\end{array}$ & $\begin{array}{c}\text { Mahayung } 1 \\
\text { (1998) }\end{array}$ & $\begin{array}{l}\text { Tupak } \\
(2001)\end{array}$ & $\begin{array}{r}\text { SP. 701 } \\
(2003)\end{array}$ & $\begin{array}{l}\text { KTU } \\
(2004) \\
\end{array}$ \\
\hline \multirow{2}{*}{ Natural forest } & Seedling & 37.64 & 15.94 & 26.82 & 0 & 9.96 & 9.96 \\
\hline & Sapling & 28.47 & 6.55 & 19.25 & 14.97 & 13.59 & 36.90 \\
\hline
\end{tabular}

namely in planting the year 1996 and planting the year 2001 with a value of 1.28 . This was due to the phenomenon that this area was open, due to a disturbance in the form of land clearing, so that there was little shade being available. The diversity of undergrowth vegetation was affected by various factors, such as vegetation species, crown cover or shade, and soil quality (Kunarso \& Azwar 2012).

Index of plant species similarity Index of community similarity (IS) shows the composition of plant species in 2 communities being compared. Data on the index of plant similarity could be seen in Table 3 . None of the vegetation communities in 6 locations of reclamation area being studied, showed any community which was similar to the natural forest. This was because the IS value did not reach $\geq 75 \%$. Soerianegara and Indrawan (2012) explained that if 2 communities possessed IS value of $0 \%$, then the 2 communities being compared are totally different, and if the IS $100 \%$, the 2 communities being compared were similar.

Vegetation community which exhibited the highest IS, namely planting the year 1995 possessed IS values at all levels, ranging from undergrowth vegetation, seedlings, saplings, poles, and trees. planting the year 1996 exhibited IS up to pole stage, whereas other reclamation areas exhibited IS value up to sapling stage. These phenomena were affected by planting age, and planting year 1995 was the oldest.

Dominance (Di) and index of diversity of bird Information on bird dominance is useful for determination of which bird species are dominant, subdominant and not dominant in observation strip (Dewi et al. 2007). A number of bird species which were found in the natural forest were 29 bird species, belonging to 20 families. Table 4 shows that in natural forest, there were 8 dominant bird species ( $\mathrm{Di}>5 \%$ ) comprising among others (ordered from that with the largest dominance):
Collocalia esculenta, Lonchura maja, Streptopelia chinensis, Anthreptes simplex, Aegithina tiphia, Pycnonotus melanicterus, Pycnonotus aurigaster, and Hirundo tahitica. There were 6 species of subdominant bird ( $\mathrm{Di}=2-5 \%)$, and there were 15 birds species which were not dominant $(0-2$ $\%)$.

Figure 7 shows that dominant bird species in the reclamation area were also the dominant species in the natural forest, except the species Prinia familiaris, Megalaima haemachepala, and Treron vernans. In a natural forest, species $P$. familiaris belonged to nondominant species; species M. haemachepala was not found, whereas $T$. vernans was subdominant species. In general, the dominant bird species were those found as more than 1 individual or in groups (Watalee et al. 2013). The species of dominant this, in general, is the species of spreading the fruit/seeds into the area reclamation. Frugivora species among others: $P$. aurigater, $P$. familiaris, $M$. haemachepala, and $T$. vernans. Frugivora contribute to the spread of seeds plants and regeneration of plants (Kominami et al. 2003).

Figure 8 shows that habitat which possessed the highest number of species and $\mathrm{H}^{\prime}$ of bird, was that of natural forest. Bird species diversity in the natural forest was higher than that in plantation forest (Badaruddin 2006). The greater the number of bird which disperses the seeds of tree species to other places, the easier would be the improvement of the environment from unvegetated area to vegetated area (Watalee et al. 2013). The greatest number of birds species and value of $\mathrm{H}^{\prime}$ in reclamation area was found in planting the year 1998. This phenomenon was due to the minimum disturbance on the habitat, and the presence of artificial lake which constituted the water and food source for the bird. In reclamation area, the richness of bird species increased with the existence of habitat heterogeneity (Salek 2012). Planting year 1995 possessed lower number of bird species and $\mathrm{H}^{\prime}$ 
value as compared with those of planting year 1998 and planting year 2003, due to disturbance and land clearing for strip of conveyor belt which was apparatus/infrastructure to transport coal from the mining area to outside the area to be processed further, and this infrastructure produce heavy noise. The noise occurring in the observation location would affect the diversity of bird species (Badaruddin 2006).

The planting year 2001 area possessed the lowest value of bird H', namely 2.06, while the number of species was 12

Table 4 Number of species and their dominance in natural forest

\begin{tabular}{|c|c|c|c|}
\hline Species & Family & $\begin{array}{l}\text { Number of } \\
\text { individuals }\end{array}$ & Di $(\%)$ \\
\hline Lonchura maja & Estrildidae & 9 & 8.57 \\
\hline Anthreptes simplex & Nectariniidae & 7 & 6.67 \\
\hline Dendrocopos canicapillus & Picidae & 1 & 0.95 \\
\hline Todirhamphus chloris & Alcedinidae & 3 & 2.86 \\
\hline Phylloscopus inornatus & Phylloscopidae & 1 & 0.95 \\
\hline Orthotomus atrogularis & Cisticolidae & 4 & 3.81 \\
\hline Orthotomus ruficep & Cisticolidae & 2 & 1.90 \\
\hline Brachypteryx leucophrys & Muscicapidae & 1 & 0.95 \\
\hline Aegithina tiphia & Aegithinidae & 7 & 6.67 \\
\hline Macronous gularis & Timaliidae & 1 & 0.95 \\
\hline Pycnonotus melanicterus & Pycnonotidae & 7 & 6.67 \\
\hline Chalcophaps indica & Columbidae & 1 & 0.95 \\
\hline Ictinaeutus mal ayensis & Accipitridae & 1 & 0.95 \\
\hline Zosterops palpebrosus & Zosteropidae & 2 & 1.90 \\
\hline Zosterops salvadorii & Zosteropidae & 1 & 0.95 \\
\hline Amaurornis phoenicurus & Rallidae & 1 & 0.95 \\
\hline Acridotheres javanicus & Sturnidae & 3 & 2.86 \\
\hline Pycnonotus aurigaster & Pycnonotidae & 7 & 6.67 \\
\hline Hirundo tahitica & Hirundinidae & 7 & 6.67 \\
\hline Pycnonotus goiavier & Pycnonotidae & 1 & 0.95 \\
\hline Prinia familiaris & Cisticolidae & 1 & 0.95 \\
\hline Arachnothera longirostra & Nectariniidae & 3 & 2.86 \\
\hline Treron vernans & Columbidae & 3 & 2.86 \\
\hline Alcedo meninting & Alcedinidae & 1 & 0.95 \\
\hline Pericrocotus flammeus & Campephagidae & 4 & 3.81 \\
\hline Loriculus galgulus & Psittaculidae & 2 & 1.90 \\
\hline Streptopelia chinensis & Columbidae & 8 & 7.62 \\
\hline Collocalia esculenta & Apodidae & 15 & 14.29 \\
\hline Cacomantis sepulcralis & Cuculidae & 1 & 0.95 \\
\hline
\end{tabular}

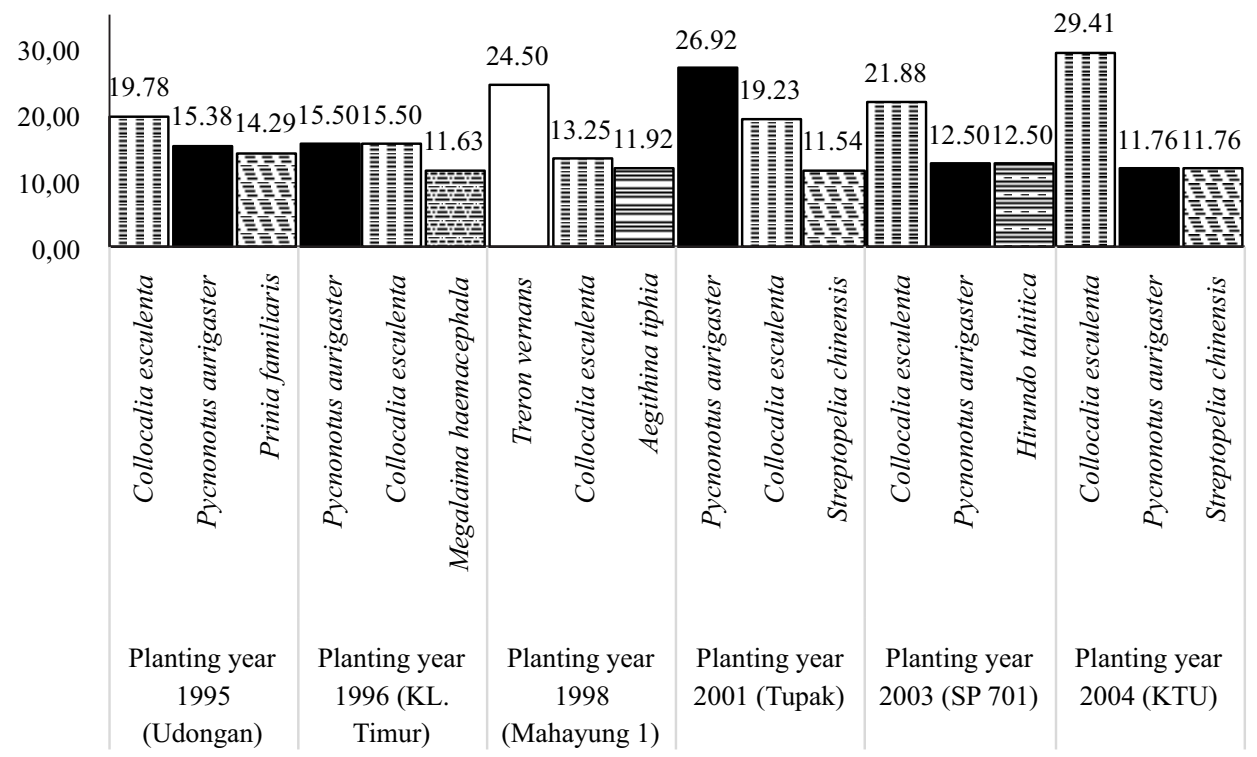

Figure 7 Three bird species with the highest dominance in the reclamation area. 
because in the location, the habitat was disturbed and there was the lack of tree vegetation for bird habitat. Diverse vegetation in a habitat would support food availability for the bird, so that with the diversity of vegetation species, the bird could get more choice of food (Tews et al. 2004).

Species similarity index of birds Index of species similarity (IS) was used to study the similarity of bird species community between research locations. Table 5 shows that bird species which were recorded in each location possessed bird IS, but with low value. This was due to the difference in the structure of vegetation and habitat. Jokimaki and Jokimaki (2013) explained that species similarity was affected by area size of the location and habitat structure. Results of the analysis show that the highest bird species IS was between natural forest habitat type and planting year 1998 with IS value of $50 \%$. There were 17 similar bird species in the 2 habitats, which were among others: Anthreptes simplex, Dendrocopos canicapillus, Todirhamphus chloris, Orthotomus ruficep, Aegithina tiphia, Macronus gularis, Ictinaeutus malayensis, Acridotheres javanicus, $P$. aurigaster, $P$. melanicterus, Hirundo tahitica, $P$. goiavier, P. familiaris, Geopelia striata, T. vernans, Streptopelia chinensis, and Collocalia esculenta. Reclamation area which possessed the lowest bird IS was planting the year 2001 with IS of $32 \%$. The low value of similarity in planting the year 2001 was due to disturbed condition of the habitat resulting from vegetation burning by local people.

Leaf area index (LAI) LAI is a variable which shows the relation between area size of leaves and area size of the area being covered (Risdiyanto \& Setiawan 2007). Also, LAI is

Table 5 Similarity indices of birds

\begin{tabular}{llc}
\hline & Locations being compared & IS of birds (\%) \\
\hline Natural forest & Udongan (1995) & 47 \\
Natural forest & KL. Timur (1996) & 35 \\
Natural forest & Mahayung 1 (1998) & 50 \\
Natural forest & Tupak (2001) & 32 \\
Natural forest & SP. 701 (2003) & 45 \\
Natural forest & KTU (2004) & 37 \\
\hline
\end{tabular}

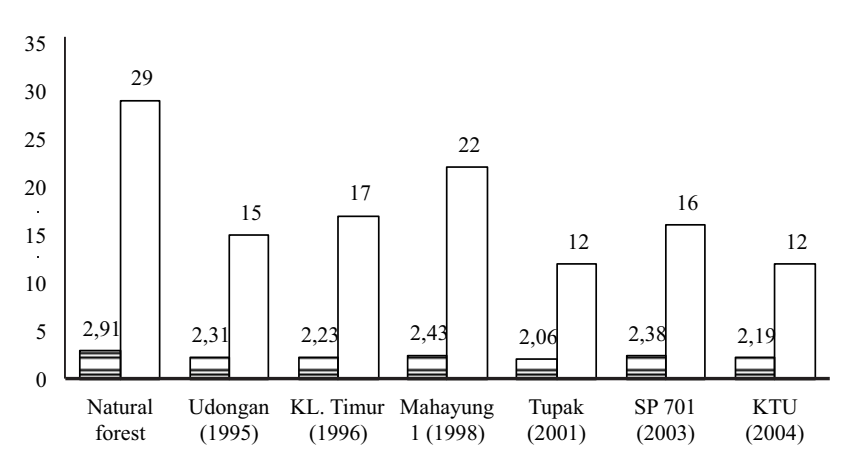

Figure 8 Number of species and diversity indices of birds. $\mathrm{H}^{\prime}($ (日)), Number of species (口). total area size of foliage per unit of ground surface area size (being projected on ground surface) (Morisette et al. 2006). Figure 9 shows the trend that the older the reclamation year, the higher was the value of LAI. With the existence of such trend, the LAI constitutes 1 of the factors which could determine forest growth. LAI is a main factor in the ecophysiological process of forest which started to grow and serves as input in a various model of ecosystem (Sprintsin et al. 2009). In the planting year 1996 and planting the year 2001, there was a decrease in LAI values, due to the phenomenon that in 1996 there was land clearing being used for settling pond of mine acid water, whereas in 2001 there was vegetation burning.

The planting year 1995 possessed LAI value which approached natural forest, namely 1.89 , indicating that the planting year 1995 could be categorized as forest. Suwarsono et al. (2011) explained that forest LAI varied, ranging from $1-3$. The value of LAI for the condition of absence of plant crown is 0 (Handoko et al. 2010). The result of hemiview photograph which was taken in a natural forest in each reclamation area in PTBA was shown in Figure 10.

\section{Conclusion}

The value of vegetation diversity index in the planting year 1995 approached that of natural forest, except for that of undergrowth vegetation. Index of similarity of plant species between reclamation area and natural forest did not show any existence of similar communities. The planting year 1995 area possessed a value of vegetation species similarity indices with natural forest, at all strata, ranging from undergrowth vegetation, seedlings, poles, and trees. Index of bird diversity in the planting year 1998 area possessed the highest value and approached that of natural forest, namely 2.43. Similarity index of bird species was highest in the planting year 1998, namely 50\%. The planting year 1995 area possessed LAI value which approached that of natural forest, namely 1.89 . The older the planting year, the higher was the LAI value, except for reclamation area which was disturbed, namely planting year 1996 and 2001.

\section{Acknowledgement}

The present research was funded by SEAMEO BIOTROP with certain period employment contract No. 0044.19/PSRP/SC/SPK-PNLT/III/2016.

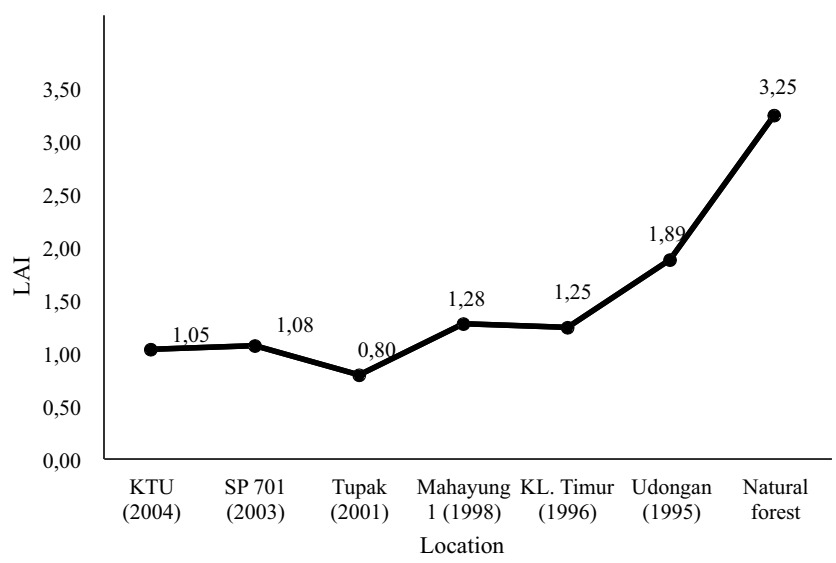

Figure 9 Average LAI in each reclamation area. 


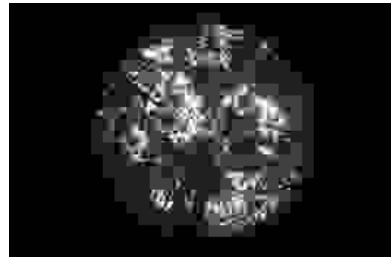

(a)

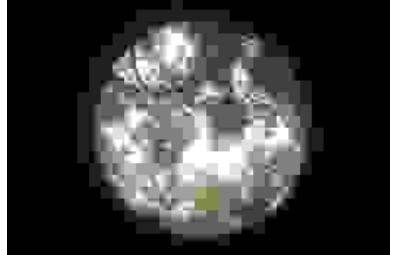

(b)

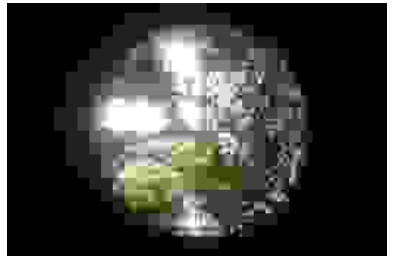

(c)

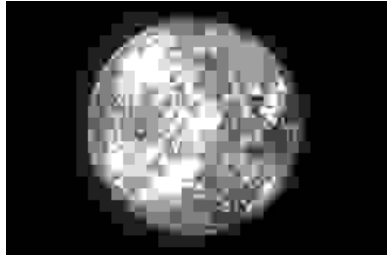

(d)

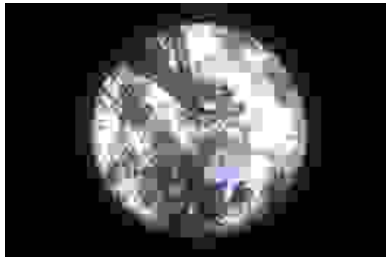

(e)

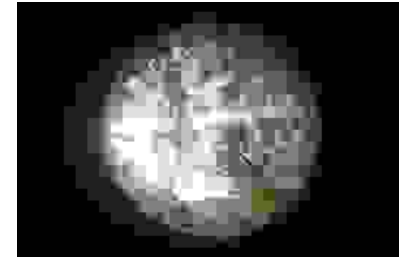

(f)

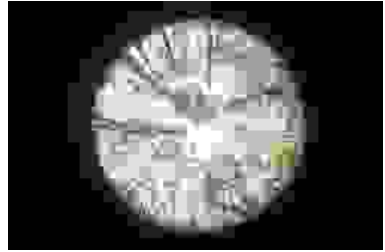

(g)

Figure 10 Hemiview photograph of (a) natural forest (b) Udongan (c) KL. Timur(d) Mahayung 1 (e) Tupak (f) SP. 701 (g) KTU.

\section{References}

Ardhana IPG. 2010. The conservation of biodiversity for mining activities in the forest areas. Jurnal Ilmu Pertanian Indonesia 15(2):71-77.

Ariani, Sudhartono A, Wahid A. 2014. Biomass and carbon of ground cover plants in lake tambing at lore lindu national park. Warta Rimba 2(1):164-170.

Bengen DG. 2000. Teknik Pengambilan Contoh dan Analisis Data Biofisik Sumber daya Pesisir. Bogor: Bogor Agricultural University.

Badaruddin E. 2006. Keragaman dan habitat satwa burung di taman wisata alam Plawangan Turgo - Yogyakarta. Jurnal Agroforestri 1(2):27-35.

Bibby C, Martin J, Stuart M. 2000. Expedition Field Techniques. Bogor: Birdlife Indonesia Programme.

Das M, Chatterjee P, Roy R. 2015. Soil and vegetation characteristics associated with mine overburdens of an opencast coalmine area of Burdwan district, West Bengal, India. International Journal of Advanced Research 3:1482-1487.

Fitriana YR. 2006. Diversity and abundance of macrozoobenthos in mangrove rehabilitation forest in great garden forest Ngurah Rai Bali. Biodiversitas 7(1):67-72. https://doi.org/10.13057/biodiv/d070117.

Gardingen V, Jackson PR, Hernandez-Daumas GE, Russell S, Sharp GL. 1999. Leaf area index estimates obtained for clumped canopies using hemispherical photography. Agricultural and Forest Meteorology 94(3-4):243-257. https://doi.org/10.1016/S0168-1923(99)00018-0.

Handoko I, Kodarsih T, Ariyani A. 2010. Canopy extinction coefficient and solar radiation use efficiency of potato crop
(Solanum tuberosum 1.) of granola cultivar grown in galudra, Cianjur, West Java. Jurnal Agromet 24(2):27-32.

Indriyanto. 2006. Forest Ecology. Jakarta: PT Bumi Aksara.

Hadisiswoyo P, Saraan M, Ardi R, Azhari A, Daley P, Wagiman. 2014. The Field Guide of Restoration Tropical Forests in Indonesia. Jakarta: Yayasan Orangutan Sumatera Lestari-Orangutan Information Centre (YOSLOIC) dan Tropical Forest Conservation Action (TFCA) Sumatera.

Hilwan I, Mulyana D, Pananjung WG. 2013. The species diversity of ground cover at sengon buto (Enterobilium cyclocarpum griseb.) and trembesi (Samanea saman merr.) plantation in PT Kitadin's post mining land, Embalut, Kutai Kartanagara, East Borneo. Jurnal Silvikultur Tropika 4(1):6-10.

Husain Z, Dharmono, Kaspul. 2010. Type and birds density in the region agropolitan in Madastana district Barito Kuala. Jurnal Wahana-Bio 4:47-58.

Jokimaki K, Jokimaki MLK. 2003. Spatial similarity of urban bird communities: a multiscale approach. Journal of Biogeography 30:1183-1193. https://doi.org/10.1046/ j.1365-2699.2003.00896.x

Kominami Y, Sato T, Takeshita K, Manabe T, Endo A, Noma N. 2003. Classification of bird-dispersed plants by fruiting phenology, fruit size, and growth form in a primary lucidophyllous forest: an analysis, with implications for the conservation of fruitbird interactions. Ornithol Science 2:3-2. https://doi.org/10.2326/osj.2.3.

Krebs CJ. 1978. Ecological Methodology. New York: Harper dan Row Publisher.

Kunarso A, Azwar F. 2013. Understorey diversity on several 
plantation forest stands in Benakat, South Sumatera. Jurnal Penelitian Hutan Tanaman 10(2):85-98.

Law of The Republic of Indonesia Number 4 of 2009 Concerning Mineral and Coal Mining.

Magurran AE. 2004. Measuring Biological Diversity. Malden: Blackwell.

Mawazin, Subiakto. 2013. Species diversity and composition of logged over peat swamp forest in riau. Journal Forest Rehabilitation 1(1):59-73.

Morisette JT, Baret F, Privette JL, Myneni RB, Nickeson J, Garrigues S, Shabanov N, Weiss M, Fernandes R, Leblanc S, Kalacska M, Azofeifa GAS, Chubey M, Rivard B, Stenberg P, Rautiainen M, Voipio P, Manninen T, Pilant AN, Lewis TE, Liames JS, Colombo R, Meroni M, Busetto L, Cohen W, Turner DP, Warner ED, Petersen GW, Seufert G, Cook R. 2006. Validation of global moderate-resolution LAI products: a framework proposed within the CEOS land product validation subgroup. IEE Transaction on Geoscience and Remote Sensing 44:1-14.

Mukhtar AS, Heriyanto NM. 2012. Plant succession at ex coal mine area in East Kalimantan. Jurnal Penelitian Hutan dan Konservasi Alam 9(4):341-350. https://doi.org/10.11 09/ TGRS.2006.872529.

Odum EP. 1993. Base of Ecology. Yogyakarta: Gajah Mada University Press.

Puspaningsih N, Murtilaksono K, Sinukaban N, Jaya INS, Setiadi Y. 2010. Reforestation achievement monitoring at mining area through soil index model. Jurnal Manajemen Hutan Tropika 16(2):53-62.

Rich PM. 1990. Characterizing plant canopies with hemispherical photograph. Remote Sensing Reviews5:13-29. https://doi.org/10.1080/027572590095 32119.

Risdiyanto I, Setiawan R. 2007. Energy balance method for determining leaf area index land using multi spectral satellite imaginary. Jurnal Agromet Indonesia 21(2):27-38.

Riswan, Harun U, Irsan C. 2015. Flora diversity at post-coal mining reclamation in the PTBA South Sumatera. Jurnal Manusia dan Lingkungan 22(2):160-168.

Saharjo BH, Gago C. 2011. Natural succession after fires at secondary forest in Fatuquero Village, Railaco District, Ermera Regency-Timor Leste. Jurnal Silvikultur Tropika
2(1):40-45.

Salek M. 2012. Spontaneous succession on opencast mining sites: implication for bird biodiversity. Journal of Applied Ecology 49:1417-1425. https://doi.org/10.1111/j.13652664.2012.02215.x.

Soerianegara I, Indrawan A. 2012. Ekologi Hutan Indonesia. Bogor: Bogor Agricultural University.

Sprintsin M, Karnieli A, Berliner P, Rotenberg E, Yakir D, Cohen S. 2009. Evaluating the performance of the MODIS leaf area index (LAI) product over a Mediterranean dryland planted forest. International Journal of Remote Sensing 30(19):5061-5069. https://doi.org/10.1080/ 01431160903032885 .

Suwarsono, Arief M, Hidayat, Sulma S, Suryo HN, Sulyantoro H, Setiawan KT. 2011. Pengembangan metode penentuan indeks luas daun pada penutupan lahan hutan dari data satelit penginderaan jauh SPOT-2. Jurnal Penginderaan Jauh 8:50-59.

Tews J, Brose U, Grimm V, Tielborger K, Wichmann MC, Schwager M, and Jeltsch F. 2004. Animal species diversity driven by habitat heterogeneity/diversity: The importance of keystone structure. Journal of Biogeography 31:79-92. https://doi.org/10.1046/j.0305-0270.2003.00994.x.

Turner DP, Cohen WB, Kennedy RE, Fassnacht KS, Briggs JM. 1999. Relationships between leaf area index and Landsat TM spectral vegetation indices across three temperate zone sites. Remote Sensing of Environment 70:52-68. https://doi.org/10.1016/S0034-4257(99) $00057-7$.

Watalee H, Ningsih S, Ramlah S. 2013. Birds density in swamp forest Saembawalati Tomui Karya Village in Mori Atas District Morowali. Warta Rimba 1(1):1-8.

Wirdateti, Setyorini LE, Suparno, Handayani TH. 2004. Feeding and habitat of slow Loris (Nycticebus coucang) in Badui Tribe conservation forest, Rangkasbitung-South Banten. Biodiversitas 6(1):45-49. https://doi.org/10. 13057/biodiv/d060109. 